\title{
PENGARUH INDEPENDENSI, KOMPETENSI, PROFESIONALISME, DAN INTEGRITAS TERHADAP KUALITAS AUDIT DENGAN ETIKA AUDITOR SEBAGAI MODERASI
}

\author{
NAILA*, SISTYA RACHMAWATI \\ Fakultas Ekonomi dan Bisnis, Universitas Trisakti \\ *Email: Nailasymln@gmail.com
}

\begin{abstract}
ABSTRAK
The purpose of this study was to examine and analyze the effect of Independence (I), Competence (K), Professionalism (P), and Integrity (IT) on Audit Quality with Auditor Ethics as Moderating variable in Public Accounting Firms. the second is located in DKI Jakarta. Samples were taken by random sampling method. The research sample was 120 respondents consisting of 6 second-tier Public Accounting Firms located in Jakarta. This research uses multiple regression analysis methods. This study has six variables, which consist of the moderating independent variable and the dependent variable. Independent variables: independence, competence, professionalism and integrity, while the dependent variable is audit quality. The moderating variable is auditor ethics. Based on the results of the study, it can be concluded that independence, competence, professionalism, and integrity have a significant positive effect on audit quality.
\end{abstract}

Keywords: Independence; Competence; Professionalism; Integrity; Audit Quality

\section{PENDAHULUAN}

Kebutuhan akan informasi mengenai laporan keuangan atas suatu perusahaan semakin tinggi, dengan adanya informasi yang tepat dan akurat diharapkan dari pihak manajemen di perusahaan dapat mengambil keputusan yang baik berdasarkan datadata atau informasi yang didapatkan dari laporan keuangan perusahaan, sehingga dapat memberikan keuntungan bagi perusahaan dan pemangku kepentingan lainnya. Menghasilkan informasi akuntansi dan laporan keuangan dalam sebuah perusahaan adalah salah satu tanggung jawab akuntan. Salah satu tugas utama akuntan di antaranya membukukan seluruh aktivitas yang bersifat ekonomis yang dilakukan oleh perusahaan secara sistematis, periodik dan mudah untuk dipahami oleh bagi pengguna laporan tersebut.

Profesi akuntansi ada beberapa jenis, salah satunya adalah akuntan publik yang mempunyai tanggung jawab di antaranya adalah meningkatkan kredibilitas para pihak terkait melalui laporan keuangan yang disusun mengikuti kriteria dan sesuai dengan prinsip akuntansi.

* Corresponding author’s e-mail: Nailasymln@gmail.com

http://openjournal.unpam.ac.id/index.php/JIA 
AAA Financial Accounting Standard Committee (2000) dalam Marito (2019) menyatakan bahwa kualitas audit ditentukan oleh dua hal, yaitu kompetensi (keahlian) dan independensi, kedua hal tersebut berpengaruh langsung terhadap kualitas dan secara potensial saling mempengaruhi. Suatu audit hendaknya dilakukan oleh orang yang berkompetensi (ahli) dan berpengalaman teknis yang memadai selaku auditor. Selain itu, pelaku audit mesti menggunakan keterampilan profesionalnya cermat dan cermat baik dalam menjalankan tugas audit maupun melaporkan laporannya. Kompetensi adalah keterampilan yang dimiliki auditor tentang pekerjaannya. Auditor yang kompeten akan menggunakan keahliannya dengan mudah, cepat, dan intuitif dalam melaksanakan pekerjaan profesi auditnya. Sehingga kompetensi memiliki pengaruh pada kualitas audit. Kompetensi menuntut auditor untuk berpendidikan formal di bidang audit, akuntansi, dan juga mempunyai cukup praktik pengalaman dalam profesi audit yang diemban. Pendidikan formal audit menuntut tiap peserta untuk berupaya keras mendapatkan tingkat kompetensi tertinggi untuk memastikan kualitas layanan dan yang mereka berikan telah memenuhi prasyarat profesionalisme sesuai dengan prinsip etika yang berlaku. Profesionalitas merupakan keahlian pengkoordinasian, perencanaan, pelaksanaan tanggung jawab secara baik dan benar dan mempunyai semangat kerja yang tinggi. Berkaitan dengan kinerja profesinya, auditor harus mempunyai prinsip dasar yang bertumpu pada kode etik, salah satunya adalah integritas.

Motivasi peneliti untuk meneliti topik ini dikarenakan peneliti ingin melakukan penelitian yang mencakup variabel yang lebih banyak mengenai apa sajakah yang berpengaruh pada kualitas audit. Yang dilaksanakan peneliti yakni berdasar pada penelitian yang sudah dijelaskan di atas dan menggabungkan dengan pengujian pengaruhnya independensi, kompetensi, profesionalisme, dan integritas pada kualitas audit. Adapun perbedaan dengan penelitian terdahulu yaitu ditambahkannya variabel integritas selaku variabel independen, dan variabel etika auditor selaku variabel moderasinya. Alasan ditambahkannya variabel integritas karena integritas dapat mempengaruhi hasil pemeriksaan. Jika integritas tinggi, maka pihak audit bisa menaikkan mutu hasil pekerjaannya

Berdasarkan latar belakang yang telah dikemukakan di atas, maka permasalahan pokok yang akan dibahas dalam penelitian ini adalah: (1) Apakah independensi auditor berpengaruh terhadap kualitas audit? (2) Apakah kompetensi auditor berpengaruh terhadap kualitas audit? (3) Apakah profesionalisme auditor berpengaruh terhadap kualitas audit? (4) Apakah integritas berpengaruh terhadap kualitas audit? (5) Apakah Etika Auditor memoderasi pengaruh independensi auditor terhadap kualitas audit? (7) Apakah Etika Auditor memoderasi pengaruh Kompetensi Auditor terhadap kualitas audit? (8) Apakah Etika Auditor memoderasi pengaruh profesionalisme auditor terhadap kualitas audit? (9) Apakah Etika Auditor memoderasi pengaruh integritas terhadap kualitas audit? 


\section{LANDASAN TEORI}

\section{Teori Audit}

Audit ialah prosedur sistematis penilaian informasi atau pernyataan untuk menilai tingkat kepatuhannya kriteria yang telah ditentukan sebelumnya, dan komunikasi hasil kepada pengguna yang tertarik. (Mulyadi, 2011). Audit terdiri dari pemeriksaan dan sertifikasi laporan keuangan oleh ahli independen untuk memberikan argumen tentang fakta dan keakuratan data yang terkandung di dalamnya. Peran audit adalah memberikan informasi kepada pengguna tentang prinsip, praktik akuntansi, penyajian laporan keuangan yang akurat, posisi keuangan yang jelas dan kinerja perusahaan.

Intinya proses audit adalah pengumpulan bukti audit yang adil (hanya karakter dari bukti yang terkait dengan kualitas dan efektivitas jenis sampel yang dikumpulkan) dan bukti yang cukup mengacu pada jumlah yang dikumpulkan yang diperlukan untuk mengekspresikan argumen atau merumuskan rekomendasi. Penilaian korespondensi atau ketidakkonsistenan antara berbagai jenis sampel yang dikumpulkan. Dalam melaksanakan tugasnya, Akuntan Publik berpedoman kepada Standar Profesional Akuntan Publik yang berfungsi sebagai SOP dan disusun oleh Dewan Standar Profesional Akuntan Publik (DSPAP) Institut Akuntan Publik Indonesia (IAPI).

\section{Standar Auditing}

Proses audit berpedoman pada standar umum, pekerjaan lapangan dan pelaporan oleh IAI (IAI, 2001). Standar audit adalah landasan proses mengaudit sejarah laporan financial yang meliputi 10 standar yang dijabarkan melalui Pernyataan Standar Auditing (PSA). Standar auditing tidak sama dengan prosedur auditing. Prosedur berhubungan pada langkah yang wajib dilakukan, jika standar berkaitan dengan syarat atau penilaian kualitas pekerjaan tersebut dan berhubungan terhadap tujuan yang akan diraih.

\section{Standar Atestasi}

Dalam Pernyataan Standar Atestasi dikatakan bahwa atestasi adalah aktivitas membuat klaim tentang properti target oleh memberikan bukti kepada penilai. Kerangka kerja terbuka untuk pengesahan adalah diinginkan untuk dukungan yang aman untuk aktivitas sensitif atau bernilai tinggi pada jaringan yang heterogen. Kami mengidentifikasi lima prinsip utama untuk memandu pengembangan pengesahan sistem. Kami berargumen bahwa (i) pengesahan harus mampu memberikan segar untuk sementara waktu bukti; (ii) informasi yang komprehensif tentang target yang diakses; (iii) target, atau pemiliknya, harus mampu membatasi pengungkapan informasi tentang target; (iv) klaim pengesahan harus mempunyai semantik eksplisit untuk memungkinkan keputusan untuk bergantung pada beberapa klaim; dan (v) pengesahan yang mendasari mekanisme harus dapat dipercaya. 


\section{Standar Jasa Akuntansi dan Review}

Standar jasa akuntansi serta review memberi panduan pada fungsi non atestasi untuk jasa akuntan publik yang meliputi jasa akuntansi serta review. Tujuan audit adalah memberikan informasi kepada pengguna tentang prinsip dan praktik akuntansi dan akuntansi dan penyajian keuangan laporan gambaran yang akurat, posisi keuangan dan keuangan yang jelas dan lengkap kinerja perusahaan.

\section{Standar Jasa Konsultansi}

Dalam Pernyataan Standar Jasa Konsultasi dikatakan bahwa akuntan public melayani jasa pengkonsultasian bagi klien melalui KAP. Proses konsultasi. Pendekatan dan proses analitis yang diterapkan dalam Layanan Konsultasi. Itu biasanya melibatkan beberapa kombinasi aktivitas yang berkaitan dengan penentuan tujuan klien, pencarian fakta, definisi masalah atau peluang, evaluasi alternatif, formulasi tindakan yang diusulkan, komunikasi hasil, implementasi, dan tindak lanjut. Konsultasi, dimana fungsi praktisi adalah memberikan nasihat secara singkat kerangka waktu, landasan, jika tidak seluruhnya, pada pengetahuan pribadi yang ada tentang klien, keadaan, hal teknis yang terlibat, representasi klien, dan niat bersama dari para pihak. Syarat jasa konsultasi adalah mempunyai kompetensi professional, perawatan, perencanaan dan pengawasan, menyediakan data relevan sebagai dasar pengambilan keputusan.

\section{Standar Pengendalian Mutu}

Dalam Pernyataan Standar Pengendalian Mutu No. 1 (PSPM No. 1) dikatakan bahwa elemen pengendalian mutu yang mesti digunakan oleh masing-masing KAP pada seluruh tipe jasa audit, atestasi serta konsultansi terdiri atas Independensi, Penugasan personel, Konsultasi, Supervisi, Pemekerjaan, Pengembangan professional, Promosi, Penerimaan dan kelanjutan klien, Inspeksi. Keberadaan Sistem Pengendalian Mutu (SPM) mutlak dibutuhkan bagi Kantor Akuntan Publik dalam upaya menjaga sekaligus mengendalikan kualitas audit (Fauji, 2015). Standar Pengendalian Mutu (SPM) memberikan panduan bagi kantor akuntan publik di dalam melaksanakan pengendalian kualitas jasa yang dihasilkan oleh kantornya dengan mematuhi berbagai standar sebagaimana Standar Profesional Akuntan Publik yang diterbitkan oleh Institut Akuntan Publik Indonesia (IAPI 2011).

\section{Tahap-tahap Opini Audit}

Pertimbangan perspektif logis dari produk akhir dari laporan keuangan pekerjaan auditor adalah laporan audit yang menunjukkan opini apakah laporan keuangan klien bebas dari materi atau tidak salah saji. Setelah menerima klien apa yang harus dilakukan auditor untuk mendapatkan yang diperlukan (dan sesuai dan cukup) bukti untuk membentuk dan mendukung pendapat itu. Selain itu Auditor harus terlebih dahulu memahami menyeluruh isi dan faktor pengaruhnya, termasuk pengendalian internal entitas. Auditor harus memahami segala resiko dari klien sehingga dapat mengembangkan strategi audit dan rencana audit yang akan menghasilkan bukti yang berguna dalam pembentukan dan pendukung pendapat atas laporan keuangan. 


\section{Kualitas Audit}

Indikator kualitas audit harus diawasi dengan cermat. Anggota parlemen, regulator, emiten, pengguna laporan keuangan, dan lain-lain telah menyerukan pengembangan indikator kualitas audit yang tersedia untuk umum. Indikator akan menguntungkan auditor, penerbit, dan pengguna laporan keuangan dengan menyediakan indikator kualitas audit yang meningkatkan transparansi perusahaan audit dan proses audit mereka. Ini membaik transparansi diharapkan dapat meningkatkan kemampuan pelaku pasar untuk menilai kualitas audit, yang pada gilirannya dapat menyebabkan diferensiasi di antara firma audit berdasarkan ukuranukuran ini, juga peningkatan insentif bagi perusahaan untuk meningkatkan kualitas audit.

\section{Etika dalam Profesi Audit}

Seorang akuntan profesional mempunyai kewajiban untuk mengevaluasi setiap ancaman terhadap kepatuhan prinsip-prinsip dasar ketika akuntan profesional tahu, atau mungkin bisa yang diharapkan untuk diketahui, tentang keadaan atau hubungan yang dapat membahayakan kepatuhan dengan Prinsip-prinsip dasar. Jenis ancaman meliputi 5 kategori:

a. Ancaman kepentingan pribadi, sewaktu seorang akuntan profesional, atau kerabat atau dekat anggota, mempunyai kepentingan finansial atau lainnya

b. Ancaman peninjauan ulang, ketika akuntan profesional mengevaluasi kembali penilaiannya sendiri

c. Ancaman advokasi, ketika seorang akuntan profesional mempromosikan pendapat itu mengkompromikan objektivitasnya sendiri

d. Ancaman keakraban, ketika seorang akuntan profesional, karena hubungan dekat, menjadi terlalu bersimpati pada kepentingan orang lain

e. Ancaman intimidasi, ketika akuntan profesional diancam untuk bertindak obyektif Selain ancaman yang jelas tidak signifikan, akuntan profesional harus mengurangi ancaman dari dalam maupun luar.

Pengamanan dibagi menjadi dua kategori:

a. Perlindungan profesi, undang-undang atau peraturan, seperti profesional standar, pengembangan profesional berkelanjutan, dan pendidikan dan pelatihan

b. Pengamanan di lingkungan kerja Tujuan pengamanan adalah untuk meningkatkan kemungkinan mengidentifikasi atau menghalangi yang tidak etis dilema. Namun, jika seorang profesional telah melanggar Kode tanpa mengetahui bahwa dia telah melakukannya jadi, begitu ketahuan, akuntan profesional harus segera melakukan tindakan perbaikan, termasuk menyiapkan pengamanan lebih lanjut. Pelanggaran mungkin atau mungkin tidak membahayakan kepatuhan bergantung pada sifat dan signifikansi masalah.

\section{Independensi}

Independensi menurut Arens et. al., (2012) dapat diartikan sebagai sudut pandang yang tidak bias. Auditor tidak hanya harus independen dalam fakta, tetapi juga harus independen dalam penampilan. Kemandirian adalah nilai fundamental 
dalam masyarakat kita. Meskipun mempunyai banyak definisi, kami mendefinisikannya sebagai memilih bagaimana menjalani hidup sendiri dalam kapasitas dan sarana yang melekat dan konsisten dengannya nilai-nilai dan preferensi pribadi seseorang. Sifat dan praktik audit (baik internal maupun eksternal) sedemikian rupa sehingga ada beberapa tantangan terhadap independensi auditor, ini mungkin ekonomi, organisasi dan sosiologis hubungan antara auditor dan pihak yang diaudit, mungkin juga demikian epistemologis dan perilaku dalam hal cara auditor memperoleh dan mengevaluasi informasi.

\section{Kompetensi}

Kompetensi dikonseptualisasikan dalam segi pengetahuan, kemampuan, keterampilan dan sikap yang ditampilkan dalam konteks serangkaian tugas profesional realistis yang dipilih dengan cermat yang mempunyai tingkat umum yang sesuai. Suatu audit semestinya dilaksanakan oleh pihak yang berkompeten (ahli) dan pengalaman teknis yang memadai selaku auditor. Selain itu, pihak audit mesti menggunakan keterampilan profesionalnya cermat dan cermat baik dalam menjalankan tugas audit maupun melaporkan laporannya. kompetensi adalah keterampilan yang dimiliki auditor tentang pekerjaannya. Auditor yang kompeten menggunakan keahliannya akan mudah, cepat, dan intuitif dalam melaksanakannya pekerjaan profesi auditnya .Sehingga kompetensi memiliki pengaruh pada kualitas audit. Kompetensi menuntut auditor untuk mendapatkan pendidikan formal mengenai audit, akuntansi, dan juga praktik. pengalaman yang cukup dalam profesi audit yang diemban, serta pendidikan profesional berkelanjutan.kompetensi audit bisa didapatkan dari pendidikan pengalaman. Tiap peserta mesti berusaha keras untuk mendapatkan tingkat kompetensi tertinggi untuk memastikan kualitas layanan dan yang mereka berikan telah memenuhi tinggi profesionalisme sesuai dengan prinsip etika yang berlaku

\section{Profesionalisme}

Profesionalisme merupakan sikap bertanggungjawab terhadap apa yang telah ditugaskan kepadanya (Agusti, 2013). Profesionalitas merupakan keahlian pengkoordinasian, perencanaan, pelaksanaan tanggung jawab secara baik dan benar dan mempunyai semangat kerja yang tinggi. Berkaitan dengan kinerja profesinya, auditor harus mempunyai suatu prinsip dasar yang bertumpu pada kode etik, salah satunya adalah integritas. Sebuah profesi melibatkan penggunaan pengetahuan ahli yang unik. Standar pengetahuan untuk keanggotaan ditentukan, standar perilaku masuk penerapan pengetahuan itu ditetapkan (keduanya harus diatur sendiri) dan sarana untuk mengembangkan pengetahuan kedua praktisi individu etika profesi sebagai sistem norma perilaku. Seperti itu norma-norma yang berhubungan dengan penggunaan pengetahuan tertentu dan, sebagian besar, menyangkut hubungan antara para ahli dan orang-orang 'awam'. Aturan perilaku itu berusaha memastikan bahwa keuntungan (tidak adil) tidak diambil oleh ahli atas orang awam yang seharusnya perbedaan pengetahuan - penerapan perlindungan pelanggan melalui pengaturan diri (profesional) 


\section{Integritas}

Menurut IAPI (2011) menyatakan bahwa setiap praktisi harus tegas dan jujur dalam melaksanakan pekerjaannya. Integritas adalah bebas dari benturan kepentingan dan tidak boleh membiarkan faktor salah saji material yang diketahuinya (Gunawan, 2012). Integritas adalah tentang norma dan nilai "moral", yang mengacu terhadap sesuatu yang benar ataupun salah, baik ataupun buruk. Fitur tersebut juga mengacu pada persetujuan umum dengan relevansi untuk semua orang dalam situasi yang sama. Itu terkait dengan nilai dan norma moral yang "valid". Integritas juga merupakan komponen profesionalisme auditor. alasan utama mengapa audit integritas dilakukan.

a. Untuk memeriksa laporan keuangan dan informasi untuk melihat apakah praktik akuntansi itu legal atau tidak. Misalnya, apakah perusahaan menggunakan dana pemerintah secara legal

b. Untuk memeriksa operasi perusahaan untuk memastikan mereka mematuhi semua hukum, kebijakan, dan peraturan. Misalnya, apakah mereka mengikuti hukum lingkungan

c. Untuk memeriksa aset seperti komputer, inventaris dan uang tunai untuk memastikannya digunakan dengan benar. Apakah mereka menggunakan komputer untuk melanggar hokum

d. Untuk memeriksa penggunaan sumber daya untuk memastikannya digunakan dengan benar dan dibeli secara legal dan dengan harga yang pantas. Misalnya, apakah mereka membeli sumber daya dari pemasok resmi dan apakah mereka menyia nyiakannya.

\section{METODE PENELITIAN}

Metode yang digunakan dalam penelitian ini adalah metode kuantitatif. Populasi penelitian ini yakni auditor di KAP Jakarta. Sampel diambil dengan metode random sampling. Sampel penelitian sebanyak 120 responden yang terdiri dari 6 Kantor Akuntan Publik yang berlokasi di Jakarta. Jenis data dalam penelitian ini adalah data primer, yang diperoleh secara langsung dari sumber asli yaitu melalui kuesioner. Penelitian ini memiliki enam variabel, yang terdiri dari variabel bebas moderasi dan variabel terikat. Variabel bebas: independensi, kompetensi, profesionalisme dan integritas, sedangkan variabel terikatnya kualitas audit dan variabel pemoderasi adalah etika auditor. Penelitian ini menggunakan metode analisis regresi berganda dengan melakukan berbagai uji sebagai berikut: Uji Kualitas Instrument, Uji Asumsi Klasik, dan Uji Hipotesis F \& t. 


\section{HASIL DAN PEMBAHASAN}

\section{Hasil}

\section{Analisis Statik Deskriptif}

Analisis statistik digunakan sebagai gambaran responden yang diteliti. Data statistik yang dimaksud meliputi jenis kelamin, usia, pendidikan terakhir, jabatan serta lamanya bekerja.

\section{Jenis Kelamin}

Total respondennya laki-laki sebesar $42 \%$ atau 42 orang dan perempuan sebesar $58 \%$ atau 58 orang. Berdasarkan hasil tersebut maka responden terbanyak adalah perempuan

2. Umur

Total responden umur 20-30 tahun sebanyak 90\% atau 90 orang, umur 31-40 tahun $5 \%$ atau 5 orang dan umur $>40$ tahun $5 \%$ atau 5 orang. Berdasarkan hasil tersebut responden yang paling banyak berkontribusi pada penelitian ini berumur 20-30 tahun.

3. Pendidikan Terakhir

Jumlah responden berdasarkan tingkat pendidikan terakhir terdiri atas D3 sejumlah 27 orang atau senilai $27 \%$, S1 sejumlah 62 orang atau senilai $62 \%$ dan S2 sejumlah 11 atau senilai $11 \%$ dari total responden. Berdasarkan persentase yang diperoleh, maka simpulannya sebagian besar responden yang ikut andil pada penelitian yakni dengan jenjang pendidikannya $\mathrm{S} 1$.

4. Jabatan

Jumlah responden berdasarkan jabatan responden terdiri atas senior manager sejumlah 4 orang atau senilai $4 \%$, manager sejumlah 8 orang atau $8 \%$, supervisor sejumlah 12 orang atau $12 \%$, senior auditor sejumlah 36 orang atau 36\%, dan junior auditor sejumlah 40 orang atau $40 \%$ dari total responden. Berdasarkan persentase yang diperoleh, maka simpulannya sebagian besar responden yang ikut andil pada penelitian yang jabatannya junior auditor.

5. Lama Bekerja

Jumlah responden berdasar lama bekerja meliputi 1-3 tahun 75 orang atau 75\%, 4-6 tahun 13 orang atau 13\%, 6-9 tahun 7 orang atau 7\% dan $>10$ tahun sejumlah 5 orang atau $5 \%$ dalam penelitian ini. Berdasarkan persentase yang diperoleh, maka simpulannya sebagian besar responden yang ikut andil pada penelitian yakni dengan lama bekerja 1-3 tahun.

\section{Uji Validitas}

Kuesioner dinyatakan valid jika pernyataannya bisa mengungkapkan suatu yang akan diukur dengan kuesioner bersangkutan. Penentuan dalam pengujian validitas yakni bila angka CITC lebih dari angka $r$-table maka bisa dinyatakan valid. Dalam menentukan $\mathrm{R}$ tabel yakni dengan menghitung df (degrees of freedom) dan besarnya df diperoleh dari formula $\mathrm{N}-2$. $\mathrm{N}$ adalah jumlah sample penelitian. Adapun banyaknya sampel yang diteliti atau $\mathrm{N}=100 \mathrm{df}=100-2=98$ dalam taraf signifikansinya $5 \%$ dan pengujian one tailed diperoleh $r$ tabel sebesar 0,165 . 
Uji validitas independensi, kompetensi, integritas, etika auditor, kualitas audit dengan menggunakan nilai Corrected Item Total Correlation terhadap 100 responden memperoleh nilai rhitung >0,165. Maka simpulannya seluruh itemnya valid dan bisa dipergunakan dalam penelitian.

\section{Uji Reliabilitas}

Reliabilitas berkaitan dengan konsistensi suatu ukuran. Berbagai macam deskriptor kualitatif yang berbeda digunakan oleh penulis untuk menafsirkan alfa nilai dihitung. Deskripsi dengan range (kecuali jika deskriptor hanya diterapkan ke satu nilai dalam sampel) mewakili nilai tertinggi dan terendah yang diberi label seperti itu dalam artikel yang disurvei. Jadi, alfa nilai-nilai digambarkan sebagai sangat baik $(0,93-0,94)$, kuat $(0,91-0,93)$, dapat diandalkan $(0,84-0,90)$, kuat $(0,81)$, cukup tinggi $(0,76-0,95)$, tinggi $(0,73-0,95)$, baik $(0,71-0,91)$, relatif tinggi $(0,70-$ $0,77)$, sedikit rendah $(0,68)$, wajar $(0,67-0,87)$, cukup $(0,64-0,85)$, sedang $(0,61-$ $0,65)$, memuaskan $(0,58-0,97)$, dapat diterima $(0,45-0,98)$, cukup $(0,45-0,96)$, tidak memuaskan $(0,4-0,55)$ dan rendah $(0,11)$

\section{Uji Normalitas}

Alat yang dipakai untuk pengujian normalitas penelitiannya ini yakni dengan One Sample Kolmogrov-Smirnov Test. uji KS berguna untuk menentukan apakah sampelnya bersumber dari populasi tertemtu dengan distribusi kontinu yang sepenuhnya ditentukan. Namun, dalam praktiknya, kita sering perlu memperkirakannya atau lebih dari parameter distribusi yang dihipotesiskan (katakanlah, distribusi normal) dari sampel, dalam hal ini nilai kritis dari uji $\mathrm{KS}$ mungkin tidak lagi valid Pengambilan keputusan mengenai normalitas One Sample Kolmogrov-Smirnov Test yakni:

1) Bila signifikansinya $>0,05$; datanya berdistribusi normal.

2) Bila signifikansinya) $<0,05$; datanya berdistribusi tidak normal.

Berdasarkan uji normalitas diketahui nilai one sample kolmogrov-smirnov > 0,05 sehingga dikatakan data berdistribusi Normal

\section{Uji Multikolinearitas}

Multikolinieritas merupakan kasus regresi berganda yang di dalamnya terdapat prediktor variabel itu sendiri sangat berkorelasi. Jika tujuannya adalah untuk memahami bagaimana berbagai $\mathrm{X}$ variabel berdampak $\mathrm{Y}$, maka multikolinieritas adalah masalah besar. Multikolinieritas adalah masalah derajat, bukan masalah ada atau tidaknya. Di hadapan multikolinearitas yang biasa penaksir kuadrat terkecil diperkirakan tidak tepat. Apabila VIF $<10$, maka tidak multikolonieritas. Apabila tolerance $>0.1$, maka tidak multikolinearitas. Berdasarkan uji multikolinearitas diketahui nilai VIF < 10 sehingga dikatakan data tidak terjadi Multikolinearitas

\section{Uji Hipotesis}

Uji t (Persamaan 1) 
Peneliti menggunakan uji t dalam mengukur pengaruhnya setiap variabel independent pada variabel terikatnya. Pengujian t tujuannya untuk menguji setiap variabel independen.

Hasil pengujian secara individual yakni:

1) Nilai t hitung 5.994 dan signifikansi independensi yakni $0.000<0.05$ (tingkat signifikansi 5\%), maka variabel independensi berpengaruh signifikan pada kualitas auditnya. Hipotesis 1 diterima.

2) Nilai t hitung 2.687 dan signifikansi variabel kompetensi yakni $0.004<0.05$ (tingkat signifikansinya 5\%), maka variabel kompetensi berpengaruh signifikan terhadap kualitas auditnya. Hipotesis 2 diterima.

3) Nilai t hitung 4.931 dan signifikansi variabel profesionalisme yakni $0.000<0.05$ (tingkat signifikansinya 5\%), maka variabel profesionalisme berpengaruh signifikan terhadap kualitas auditnya. Hipotesis 3 diterima.

4) Nilai thitung 3.254 dan signifikansi variabel integritas yakni $0.001<0.05$ (tingkat signifikansinya 5\%), maka variabel integritas berpengaruh signifikan terhadap kualitas auditnya. Hipotesis 4 diterima.

5) Nilai t hitung 2.094 dan signifikansi variabel kontrol jabatan yakni $0.020<0.05$ (tingkat signifikansinya 5\%), maka kontrol jabatan berpengaruh signifikan terhadap reporting delay.

6) Nilai t hitung 0.844 signifikansi variabel kontrol lama bekerja yakni $0.201>0.05$ (tingkat signifikansinya 5\%), maka variabel kontrol lama bekerja tidak signifikan mempengaruhi terhadap reporting delay.

Uji t (Persamaan 2)

Untuk mengetahui pengaruh moderasi melalui uji interakasi atau Moderated Regression Analysis. Hasil uji Moderated Regression Analysis dengan tingkat signifikansi 5\% yakni:

1) Nilai t hitung 3.172 dengan arah negatif dan signifikansi variabel independensi yang dimoderasi etika auditor sebesar $0.001<0.05$, maka simpulannya secara individual variabel independensi yang dimoderasi etika auditor berpengaruh signifikan terhadap kualitas auditnya. Hipotesis 5 diterima.

2) Nilai thitung 1.389 dengan arah negatif dan signifikansi variabel kompetensi yang dimoderasi etika auditor sebesar $0.084>0.05$, maka simpulannya secara individual variabel kompetensi yang dimoderasi etika auditor berpengaruh tidak signifikan terhadap kualitas auditnya. Hipotesis 6 ditolak.

3) Nilai t hitung 1.748 dan signifikansi variabel profesionalisme yang dimoderasi etika auditor sebesar $0.042<0.05$, maka simpulannya secara individual variabel profesionalisme yang dimoderasi etika auditor berpengaruh signifikan terhadap kualitas auditnya. Hipotesis 7 diterima.

4) Nilai t hitung 2.146 dan signifikansi variabel integritas yang dimoderasi etika auditor yakni $0.018<0.05$ (tingkat signifikansinya $5 \%$ ), variabel integritas yang dimoderasi etika auditor berpengaruh signifikan terhadap kualitas auditnya. Hipotesis 8 diterima. 


\section{Pengaruh Independensi Auditor terhadap Kualitas Audit}

Pada Hipotesis 1 diperoleh hasil sig 0.000 Independensi Auditor artinya variable indipenden auditor mempengaruhi Kualitas Audit maka uji hipotesis 1 diterima. Hal ini sesuai dengan yang diteliti oleh Agusi dan Pertiwi (2013) menyatakan yakni kompetensi, independensi, dan profesionalisme signifikan mempengaruhi kualitas audit. Hasil penelitian oleh Murti (2017) dan Rahayu (2016) juga menyatakan bahwa independensi auditor berpengaruh terhadap kualitas audit.

Hasil dari penelitian sependapat dengan teori yang telah diuraikan pada landasan teori, independensi adalah kegiatan auditor untuk beroperasi secara independen. Tanpa basis pengetahuan yang independen, auditor akan melakukan tindakan yang independen bergantung pada representasi yang dibuat oleh pihak yang diaudit terlepas dari tingkatnya kemandirian pikiran atau penampilan. Semakin besar auditor bersikap indipenden maka kualitas audit semakin bagus. Dalam audit perusahaan, meningkat pentingnya komite audit dalam kerangka tata kelola perusahaan, sejauh, memoderasi kekuasaan ini, tetapi hubungan antara auditor dan manajemen eksekutif tetap kunci penting dalam sebagian besar audit

\section{Pengaruh Kompetensi Auditor terhadap Kualitas Audit}

Pada Hipotesis 2 diperoleh nilai sig 0.009 pada variable kompetensi Auditor maka Kompetensi Auditor mempengaruhi Kualitas Audit sehingga Ha2 diterima. Hal ini sesuai dengan yang diteliti oleh Castellani (2008) yang mengungkapkan kompetensi dan independensi auditor signifikan mempengaruhi kualitas audit. penelitian Arianti (2014) dan In (2019) juga menyatakan bahwa kompetensi auditor berpengaruh terhadap kualitas audit.

Suatu audit semestinya dilaksanakan oleh pihak yang kompeten (ahli) dan pengalaman teknis yang memadai selaku auditor. Selain itu, auditor semestinya menggunakan keterampilan profesionalnya secara cermat baik dalam menjalankan tugas audit maupun melaporkan laporannya. Kompetensi adalah keterampilan yang dimiliki auditor tentang pekerjaannya. Auditor yang kompeten menggunakan keahliannya akan mudah, cepat, dan intuitif dalam melaksanakan pekerjaan profesi auditnya. Sehingga kompetensi memiliki pengaruh pada kualitas audit. Kompetensi menuntut auditornya untuk berpendidikan formal mengenai audit, akuntansi, dan juga praktik. pengalaman yang cukup dalam profesi audit yang diemban, serta pendidikan profesional berkelanjutan. Tiap peserta harus berusaha keras untuk mendapatkan tingkat kompetensi tertinggi untuk memastikan kualitas layanan dan yang mereka berikan telah memenuhi profesionalisme sesuai dengan prinsip etika yang berlaku.

\section{Pengaruh Profesionalisme Auditor terhadap Kualitas Audit}

Pada Hipotesis 3 nilai sig 0.000 variable Profesionalisme Auditor berpengaruh terhadap Kualitas Audit maka Ha3 diterima. Hasil penelitian ini sejalan dengan peneltian Lesmana (2015), Mayasari (2013) dan Kristianto (2017) bahwa profesionalisme auditor berpengaruh terhadap kualitas audit. Sebuah profesi melibatkan penggunaan pengetahuan ahli yang unik. Standar pengetahuan untuk keanggotaan yang telah ditentukan, standar perilaku, penerapan pengetahuan dan sarana untuk mengembangkan pengetahuan praktisi individu sebagai sistem norma 
perilaku. Seperti itu norma-norma yang berhubungan dengan penggunaan pengetahuan tertentu dan, sebagian besar, menyangkut hubungan antara para ahli dan orang-orang 'awam'.

\section{Pengaruh Integritas terhadap Kualitas Audit}

Pada Hipotesis 4 nilai sig $0.002<0.05$ pada variabel Integritas mempunyai arti Integritas mempengaruhi terhadap Kualitas Auditnya maka Ha4 diterima. Hasil penelitian ini sejalan dengan penelitian arianti (2014), sari (2011) dan Harjanto (2014) bahwa intregitas berpengaruh terhadap kualitas audit Integritas juga merupakan komponen profesionalisme auditor. Alasan utama mengapa integritas dilakukan.

a. Untuk memeriksa laporan keuangan dan informasi untuk melihat apakah praktik akuntansi itu legal atau tidak. Misalnya, apakah perusahaan menggunakan dana pemerintah secara legal

b. Untuk memeriksa operasi perusahaan untuk memastikan mereka mematuhi semua hukum, kebijakan, dan peraturan. Misalnya, apakah mereka mengikuti hukum lingkungan

c. Untuk memeriksa aset seperti komputer, inventaris dan uang tunai untuk memastikannya digunakan dengan benar. Apakah mereka menggunakan komputer untuk melanggar hokum

d. Untuk memeriksa penggunaan sumber daya untuk memastikannya digunakan dengan benar dan dibeli secara legal dan dengan harga yang pantas. Misalnya, apakah mereka membeli sumber daya dari pemasok resmi dan apakah mereka menyia-nyiakannya.

\section{Etika Auditor sebagai Moderasi Pengaruh Independensi Auditor terhadap Kualitas Audit}

Pada Hipotesis 5 angka signifikansi variabel independensi yang dimoderasi etika auditor yakni $0.001<0.05$ (tingkat signifikansinya 5\%), artinya variabel independensi yang dimoderasi etika auditor mempengaruhi secara signifikan terhadap kualitas auditnya. Hal ini dikarenakan bahwa auditor di KAP DKI Jakarta memiliki pengalaman bagus sehingga laporan finansialnya yang diauditpun bagus. Hasil penelitiannya menggambarkan bahwa Indepensi Auditor dengan dimoderasi etika auditor menguatkan hubungan antara Independensi Auditor dengan kualitas auditnya.

\section{Etika Auditor sebagai Moderasi Pengaruh Kompetensi Auditor terhadap Kualitas Audit}

Pada Hipotesis 6 angka signifikansi variabel kompetensi yang dimoderasi etika auditor yakni $0.084>0.05$ (tingkat signifikansinya 5\%), artinya variabel kompetensi yang dimoderasi etika auditor berpengaruh tidak signifikan terhadap variabel kualitas auditnya. Hal ini dapat disimpulkan, yakni etika auditor dalam bekerja tidak berjalan sesuai standar peraturan. Jika auditor mematuhi peraturan dalam bertindak maka masalah etika tidak akan pernah muncul. Hasil penelitiannya menggambarkan bahwa kompetensi dengan dimoderasi etika auditor tidak berhubungan antara kompetensi dengan kualitas auditnya. 


\section{Etika Auditor sebagai Moderasi Pengaruh Profesionalisme Auditor terhadap Kualitas Audit}

Pada Hipotesis 7 nilai sig yakni $0.042<0.05$ (tingkat signifikansinya 5\%), yang berarti variabel profesionalisme yang dimoderasi etika auditor berpengaruh terhadap variabel kualitas auditnya. Hipotesis 7 diterima. Profesionalitas merupakan keahlian pengkoordinasian, perencanaan, pelaksanaan tanggung jawab secara baik dan benar dan mempunyai semangat kerja yang tinggi. Berkaitan dengan kinerja profesinya, auditor harus mempunyai suatu prinsip dasar yang bertumpu pada kode etik, salah satunya adalah integritas. Untuk memeriksa laporan keuangan dan informasi untuk melihat apakah praktik akuntansi itu legal atau tidak. Misalnya, apakah perusahaan menggunakan dana pemerintah secara legal. Hasil penelitiannya menggambarkan bahwa Profesionalisme dengan dimoderasi etika auditor menguatkan hubungan antara Profesionalisme dengan kualitas auditnya.

\section{Etika Auditor Sebagai Moderasi Pengaruh Integritas Auditor terhadap Kualitas} Audit

Pada Hipotesis 8 angka signifikansi yakni $0.018<0.05$ (tingkat signifikansinya 5\%), artinya variabel integritas yang dimoderasi etika auditor berpengaruh signifikan dan positif terhadap variabel kualitas auditnya. Hipotesis 8 diterima. Seorang akuntan profesional mempunyai kewajiban untuk mengevaluasi setiap ancaman terhadap kepatuhan prinsip-prinsip dasar ketika akuntan profesional tahu, atau mungkin bisa yang diharapkan untuk diketahui, tentang keadaan atau hubungan yang dapat membahayakan kepatuhan dengan Prinsip-prinsip dasar. Hasil penelitiannya menggambarkan bahwa Integritas dengan dimoderasi etika auditor menguatkan hubungan antara Profesionalisme dengan kualitas audit.

\section{KESIMPULAN DAN SARAN}

Berdasar hasil analisis data yang sudah didapatkan, maka simpulannya yakni:

a. Independensi auditor mempengaruhi kualitas audit

b. Kompetensi auditor mempengaruhi kualitas audit

c. Profesionalisme auditor mempengaruhi kualitas audit

d. Integritas mempengaruhi kualitas audit

e. Independensi auditor dengan dimoderasi etika auditor menguatkan hubungan antara independensi auditor dengan kualitas auditnya.

f. Kompetensi dengan dimoderasi etika auditor tidak memperkuat atau melemahkan hubungan antara kompetensi dengan kualitas auditnya.

g. Profesionalisme dengan dimoderasi etika auditor menguatkan hubungan antara profesionalisme dengan kualitas audit

h. Integritas dengan dimoderasi etika auditor menguatkan korelasi diantara profesionalisme dan kualitas audit. 
Berdasar pada hasil analisa, pembahsan dan kesimpulannya, berikut ini implikasinya dari penelitian yang dilaksanakan, dicerminkan berbentuk saran yang disampaikan lewat hasil penelitian supaya memperoleh hasil yang lebih bagus lagi, yakni:

a. Diharapkan penelitian berikutnya agar bisa menambah jumlah sampel

b. Diharapkan penelitian selanjutnya menggunakan metode PLS (Partial Least Squares)

c. Peneliti berikutnya diharap bisa memperlebar area cakupannya yang lebih luas

d. Diperlukan kesadaran dari pengaudit untuk selalu memaksimalkan berbagai nilai dari kompetensi yang ia miliki.

\section{DAFTAR PUSTAKA}

Agusti, R., \& Pertiwi, N. P. (2013). Pengaruh Kompetensi, Independensi Dan Profesionalisme Terhadap Kualitas Audit (Studi Empiris Pada Kantor Akuntan Publik Se Sumatera). Jurnal Ekonomi, 21(03).

Arens, Alvin A., Randal J. Elder, Dan Beasley Mark S. 2012. Auditing And Assurances Services And Integrated Approach. Edisi Kedua Belas. Prentice Hall.

Arianti, K. K., \& Rahardja, R. (2014). Pengaruh Kompetensi Auditor Terhadap Kualitas Audit Dengan Kecerdasan Spiritual Sebagai Variabel Moderating (Studi Persepsi Auditor Pada Badan Pengawasan Keuangan Dan Pembangunan Provinsi Jawa Tengah) (Doctoral Dissertation, Fakultas Ekonomika Dan Bisnis).

Arianti, K. P., Edy Sujana, S. E., Adiputra, I. M. P., \& Se, S. (2014). Pengaruh Integritas, Obyektivitas, Dan Akuntabilitas Terhadap Kualitas Audit Di Pemerintah Daerah (Studi Pada Inspektorat Kabupaten Buleleng). Jimat (Jurnal Ilmiah Mahasiswa Akuntansi) Undiksha, 2(1).

Castellani, "Pengaruh Kompetensi Dan Independensi Auditor Pada Kualitas Audit", Jurnal Trikonomika, 2, Desember, 2008, Hlm. 123-132.

Fauji, L., Sudarma, M., \& Achsin, M. (2015). Penerapan Sistem Pengendalian Mutu dalam Meningkatkan Kualitas Audit. Jurnal Akuntansi Multiparadigma, 6(1), 38-52.

Ghozali, I. (2019). Aplikasi Analisis Multivariate Dengan Program Spss. Journal Of Chemical Information And Modeling. Https://Doi.Org/10.1017/Cbo9781107415324.004

Gunawan, L. D. (2012). Pengaruh Tingkat Independensi, Kompetensi, Obyektifitas, Dan Integritas Auditor Terhadap Kualitas Audit Yang Dihasilkan Kantor Akuntan Publik Di Surabaya. Jurnal Ilmiah Mahasiswa Akuntansi, 1(4), 4448. 
Harjanto, A. P., \& Zulaikha, Z. (2014). Pengaruh Kompetensi, Independensi, Objektivitas, Akuntabilitas Dan Integritas Terhadap Kualitas Audit Dengan Etika Auditor Sebagai Variabel Moderasi (Studi Empiris Kap Di Semarang) (Doctoral Dissertation, Fakultas Ekonomika Dan Bisnis).

In, A. W. K., \& Asyik, N. F. (2019). Pengaruh Kompetensi Dan Independensi Terhadap Kualitas Audit Dengan Etika Auditor Sebagai Variabel Pemoderasi. Jurnal Ilmu Dan Riset Akuntansi (Jira), 8(8).

Institut Akuntan Publik Indonesia. 2011. Standar Profesi Akuntan Publik. Jakarta : Salemba Empat.

Kristianto, O., \& Hermanto, S. B. (2017). Pengaruh Profesionalisme Auditor, Independensi Auditor, Dan Kompetensi Auditor Terhadap Kualitas Audit. Jurnal Ilmu Dan Riset Akuntansi (Jira), 6(11).

Lesmana, R., \& Machdar, N. M. (2015). Pengaruh Profesionalisme, Kompetensi, Dan Independensi Auditor Terhadap Kualitas Audit. Jurnal Akuntansi, Fakultas Ekonomi Institut Teknologi Dan Bisnis Kalbis, 2(1), 33-40.

Marito, R. C., \& Prasetya, E. R. (2019). Pengaruh Kecakapan Profesional, Pendidikan Berkelanjutan Dan Independensi Pemeriksa Terhadap Kualitas Hasil Pemeriksaan. Jurnal Ilmiah Akuntansi Universitas Pamulang, 7(2), 159-172.

Mayasari, I. (2013). Pengaruh Profesionalisme Auditor Dan Masa Perikatan Audit Terhadap Kualitas Audit (Penelitian Pada Kantor Akuntan Publik Di Bandung Yang Terdaftar Di Bapepam-Lk). Universitas Komputer Indonesia, Bandung. Hal, 1-9.

Murti, G. T., \& Firmansyah, I. (2017). Pengaruh Independensi Auditor Terhadap Kualitas Audit. Jurnal Aset (Akuntansi Riset), 9(2), 105-118.

Mulyadi. (2011). Auditing 1. Salemba Empat.

Pertiwi, N., \& Agusti, R. (2013). Pengaruh Kompetensi, Independensi Dan Profesionalisme Terhadap Kualitas Audit (Studi Empiris Pada Kantor Akuntan Publik Se Sumatera). Jurnal Ekonomi Universitas Riau.

Rahayu, T., \& Suryono, B. (2016). Pengaruh Independensi Auditor, Etika Auditor, Dan Pengalaman Auditor Terhadap Kualitas Audit. Jurnal Ilmu Dan Riset Akuntansi (Jira), 5(4).

Sari, N. N., \& Laksito, H. (2011). Pengaruh Pengalaman Kerja, Independensi, Objektivitas, Integritas, Kompetensi Dan Etika Terhadap Kualitas Audit (Doctoral Dissertation, Universitas Diponegoro 